\title{
The genotype determination and molecular characterization of bovine leukemia virus in Turkey
}

\author{
Feray Alkan $^{1 *}$, Ilke Karayel-Hacioglu1, Selda Duran Yelken², and Nuvit Coskun ${ }^{3}$ \\ ${ }^{1}$ Department of Virology, Faculty of Veterinary Medicine, Ankara University, Diskapi, Ankara, Turkey \\ ${ }^{2}$ Department of Virology, Faculty of Veterinary Medicine, Siirt University, Siirt, Turkey \\ ${ }^{3}$ Department of Virology, Faculty of Veterinary Medicine, Kafkas University, Kars, Turkey
}

\begin{abstract}
ALKAN, F., I. KARAYEL-HACIOGLU, S. DURAN YELKEN, N. COSKUN: The genotype determination and molecular characterization of bovine leukemia virus in Turkey. Vet. arhiv 91, 237-247, 2021.
\end{abstract}

\section{ABSTRACT}

Bovine leukemia virus (BLV) infection is widespread worldwide and causes significant economic losses in the livestock industry. In this study, to identify the genotypes and to investigate the molecular characterization of BLV strains, we analyzed $25 \mathrm{BLV}$ strains from cattle housed in six herds located in several Turkish geographical regions. Phylogenetic analysis, based on a partial or full-length sequence of the env gp51 gene of BLVs, showed that all Turkish BLVs belonged to genotype 1. The alignment of the deduced amino acid sequences demonstrated fourteen amino acid substitutions in different regions of the env gp51. This study updates our knowledge of BLV in Turkey. Further studies are needed to understand the molecular epidemiology and implement a comprehensive BLV control program in Turkey.

Key words: bovine leukemia virus; genotype 1; envelope glycoprotein (gp51); molecular characterization; Turkey

\section{Introduction}

Bovine leukemia virus (BLV) is known as the etiologic agent of enzootic bovine leucosis, which is the most common neoplastic disease of cattle (GAUTAM et al., 2018). Generally, BLV-infected animals remain persistently infected with no outward signs of infection (POLAT et al., 2015). BLV causes significant economic losses in the livestock industry by decreasing the milk yield, reducing reproduction efficiency, increasing diagnostic and veterinary care, reducing carcass value, shortening lifespan, and also affecting international trade (POLAT et al., 2017b; PHIRI et al., 2019).
BLV belongs to the genus Deltaretrovirus of the family Retroviridae, and its genomic organization possesses structural and enzymatic gag, pro, pol, and env genes, the regulatory genes tax and rex, accessory genes $R 3$ and $G 4$, and two identical long terminal repeats (LTR) (POLAT et al., 2017a; GAUTAM et al., 2018). The env gene encodes the envelope (Env) glycoprotein which is composed of mature extracellular protein, gp51, and a transmembrane protein, gp30. The env gp51 has an essential role in viral infectivity, and is also the primary target of neutralizing antibodies (MAMOUN et al., 1990;

\footnotetext{
*Corresponding author:

Feray Alkan, Sehit Omer Halisdemir Street, Ankara University, Faculty of Veterinary Medicine, Diskapi, 06110, Ankara, Turkey, E-mail: falkan@ankara.edu.tr
} 
JOHNSTON and RADKE, 2000). The N-terminal half of BLVgp51 plays an important role in viral infectivity and syncytium formation, and comprises three conformational epitopes, $\mathrm{F}, \mathrm{G}$, and $\mathrm{H}$, whereas the C-terminal half contains the linear epitopes A, B, D, and E (BRUCK et al., 1982). Because of the important biological functions of gp51, studies of BLV genotypes for phylogenetic and epidemiological analyses have primarily focused on the env gp51 (POLAT et al., 2016; BAZZUCCHI et al., 2019; PHIRI et al., 2019). Globally, at least 11 different BLV genotypes (genotype 1 to genotype 11) have been identified (YU et al., 2019). The literature on the distribution of the genotypes shows an interaction between some geographical regions and genotypes of BLV. Thus, genotypes 2, 5, 6, and 9 were found mostly in South American countries, genotypes 7 and 8 in Russia and Eastern European countries, genotype 10 in Thailand, China, and Myanmar, and genotypes 1, 3, and 4 on almost all continents (FECHNER et al., 1997; MORATORIO et al., 2010; OCHIRKHUU et al., 2016; POLAT et al., 2016; YANG et al., 2016; PANDEY et al., 2017; POLAT et al., 2017a; 2017b). Genotype 11, most recently identified, was detected in China (YU et al., 2019). To date, little is known about the genotypes of BLV in Turkey (ALKAN et al., 2011; DEGIRMENCI, 2011). This study presents the genotypes and the molecular characterization of BLV strains from herds located in several Turkish geographical regions, updates our knowledge of BLV in Turkey, and also contributes to future epidemiological studies.

\section{Materials and methods}

History of the study and samples. In this study, 95 blood samples were used from six organized farms, which are closed and have been restocked solely from internal animal sources, located in different regions (Fig. 1, Table 1). Animals over one year of age are kept under the same roof, although newborns are grouped under different roofs for every 3 months of age. However, they do mingle freely during grazing. First, blood samples which had been detected as positive for antibodies against gp51 by a commercial indirect ELISA kit (IDEXX, Europe B.V., Hoofddorp, the Netherlands) were used to determine the presence of BLV by PCR. Then the partial or full-length sequences of the env gene of BLVs from the selected samples $(n=25)$ were analyzed (Table 1). These were selected as samples representing different farms and sampling years.

DNA extraction and PCR amplification of env gene. All blood samples were analyzed for amplification of the partial sequence of the BLV env gene using nested PCR. Total DNA was extracted by using the QIAamp ${ }^{\circledR}$ DNA Mini Kit (QIAGEN, Germany) following the manufacturer's recommended protocol. All extracts were stored at $-80{ }^{\circ} \mathrm{C}$ until tested. PCR was performed for detection of BLV using the primers targeting the env gene region, as suggested by the OIE Manual of Diagnostic Tests and Vaccines for Terrestrial Animals (OIE (World Organization for Animal Health), 2018). For env gene amplifications, $e n v-1 \quad$ (5'-TCTGTGCCAAGTCTCCCAGATA-3') and $e n v-2$ (5'-AACAACAACCTCTGGGAAGGG-3') were used as outer primers; env-3 (5'-CCCACAAGGGCGGCGCCGGTTT-3') and env-4 (5'-GCGAGGCCGGGTCCAGAGCTGG-3') were used as inner primers, as previously described (FECHNER et al., 1996). Also, in order to detect the full-length BLV env gp51 gene (903 bp), PCR was performed using the following primers: forward, 5'-ATGCCYAAAGAACGACGG-3'; and reverse, 5'-CGACGGGACTAGGTCTGACCC-3' (MORATORIO et al., 2010). PCRs were performed using DreamTaq DNA Polymerase (Thermo Scientific, USA) according to the manufacturer's recommendations. The amplification products were analyzed by $1 \%$ agarose gel electrophoresis and visualized under UV light. The purified products of the partial and full-length env gp51 gene with expected sizes were sequenced in both directions, with the same primers used for amplification.

Cognate sequences of reference BLVs representing different genotypes for gp51 proteinencoding genes were retrieved from GenBank through the BLAST engine. Multiple sequence alignments were prepared by the MUSCLE algorithm, as implemented in Aliview Software (LARSSON, 2014). The phylogenetic tree of a $400 \mathrm{bp}$ fragment of BLV env g51 sequence was 
F. Alkan et al.: Genotyping of BLV strains from Turkey

Table 1. Distribution of the samples according to dairy farms, years and their accession numbers based on partial/ full-length env gp51 gene

\begin{tabular}{|c|c|c|c|c|}
\hline \multirow[b]{2}{*}{ Farm No / City } & \multirow{2}{*}{$\begin{array}{l}\text { Sampling } \\
\text { Year }\end{array}$} & \multicolumn{2}{|c|}{ The number of samples } & \multirow{2}{*}{$\begin{array}{c}\text { Accession No. } \\
\text { (partial/full-length* env gp51) }\end{array}$} \\
\hline & & BLV positive & Sequenced & \\
\hline I / Kirklareli & 2012 & 22 & 3 & $\begin{array}{c}\text { MH500043 } \\
\text { MH500044* } \\
\text { MH500045 }\end{array}$ \\
\hline II / Balikesir & 2012 & 4 & 2 & $\begin{array}{l}\text { MH500040 } \\
\text { MH500046 }\end{array}$ \\
\hline \multirow{4}{*}{ III / Bursa } & 2012 & 3 & 2 & $\begin{array}{l}\text { MH500041 } \\
\text { MH500047 }\end{array}$ \\
\hline & 2013 & 10 & 2 & $\begin{array}{l}\text { MN928514 } \\
\text { MN928528* }\end{array}$ \\
\hline & 2014 & 5 & 2 & $\begin{array}{l}\text { MN928526 } \\
\text { MN928525 }\end{array}$ \\
\hline & 2015 & 5 & 2 & $\begin{array}{l}\text { MN928515 } \\
\text { MN928516 }\end{array}$ \\
\hline \multirow[b]{2}{*}{ IV / Ankara } & 2014 & 9 & 1 & MN928517 \\
\hline & 2015 & 5 & 2 & $\begin{array}{l}\text { MN928518 } \\
\text { MN928519 }\end{array}$ \\
\hline V/Adana & 2016 & 9 & 1 & MN928527 \\
\hline VI / Sanliurfa & 2016 & 23 & 8 & $\begin{array}{c}\text { MH500038 } \\
\text { MH500039 } \\
\text { MH500042* } \\
\text { MN928520 } \\
\text { MN928521 } \\
\text { MN928522 } \\
\text { MN928523 } \\
\text { MN928524 }\end{array}$ \\
\hline
\end{tabular}

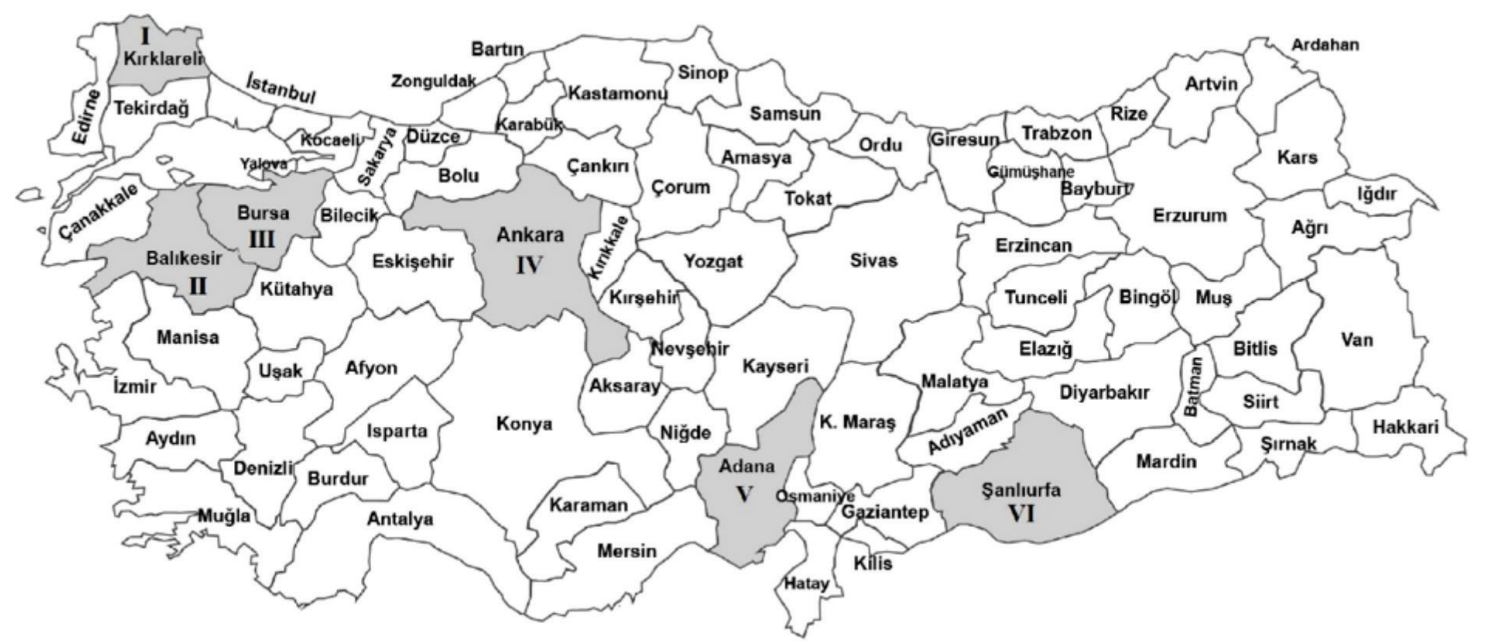

Fig. 1. The map showing the cities (with gray colors) where the farms (I to VI) sampled in this study 


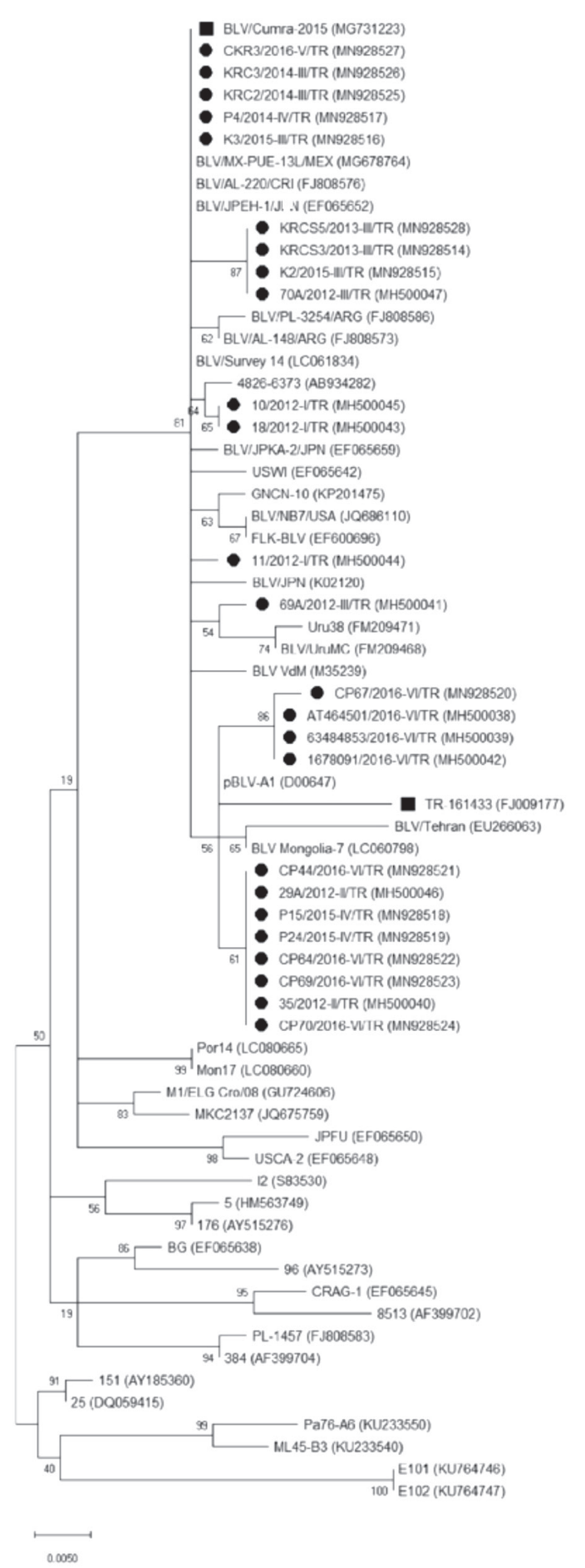

Fig. 2. Maximum likelihood phylogenetic tree based on the partial nucleotide sequences of the env gp51 gene (400 bp). The strains investigated in this study are indicated by black dots (name/year-farm no/ Turkey). The genotype 1 strains previously detected in Turkey are indicated by black squares. constructed using the Find Best Model in MEGA X: Molecular Evolutionary Genetics Analysis across computing platforms (KUMAR et al., 2018). Thus, Maximum Likelihood methods with the Kimura 2-parameter model, plus gamma distribution and 1000 bootstrap replicates were performed. The nucleotide (nt) and amino acid (aa) identities were calculated using online tools (SIAS, http://imed. med.ucm.es/Tools/sias.html).

\section{Results}

The results showed that all samples $(n=95)$ yielded amplicons of env gp51 fragments of the expected size. Of these, 25 selected amplicons were sequenced. Also, it was possible to obtain sequencing data for the full-length gp 51 gene region of three samples from different farms. The genome sequences of the BLVs identified in this study were deposited in GenBank under the following accession numbers: MH500038-MH500047 and MN928514-MN928528 (Table 1).

The phylogenetic tree, based on partial env gp51 sequences of the Turkish strains and the reference strains representing genotypes 1-11 from different countries that were available from GenBank, showed that all of our strains belonged to genotype 1 (Fig. 2). Our partial env gp51 sequence (400 bp) identities calculated by SIAS showed 98.5$100 \% \mathrm{nt}$ and $98.5-100 \%$ aa identity to each other, and $97.7-100 \%$ nt and $96.2-100 \%$ aa identity to env gp51 sequences in genotype 1 from several other countries. In addition, the nearly full-length sequence consensus ( $874 \mathrm{bp}$ ) of env gp51 for 3 BLVs (MH500042, MH500044, and MN928528) shared $98.8-99.1 \%$ and $98.6-99.6 \%$ nt identity to each other and env gp51 sequences in genotype 1 from several other countries, respectively. They also shared $98.6-99.3 \%$ and $97.9-99.6 \%$ aa identity to each other and env gp51 sequences in genotype 1 from several other countries, respectively.

The alignment of the nucleotide sequences (partial or full-length env gp51) of the 25 Turkish BLV strains with that of the Japanese K02120 demonstrated that a total of 32 mutations were found in our BLV strains. These mutations were G10A, A11G, C75T, G83C, T99C, T172C, A207C, T261C, C270T, C280A, C283A, G286A G363C, 

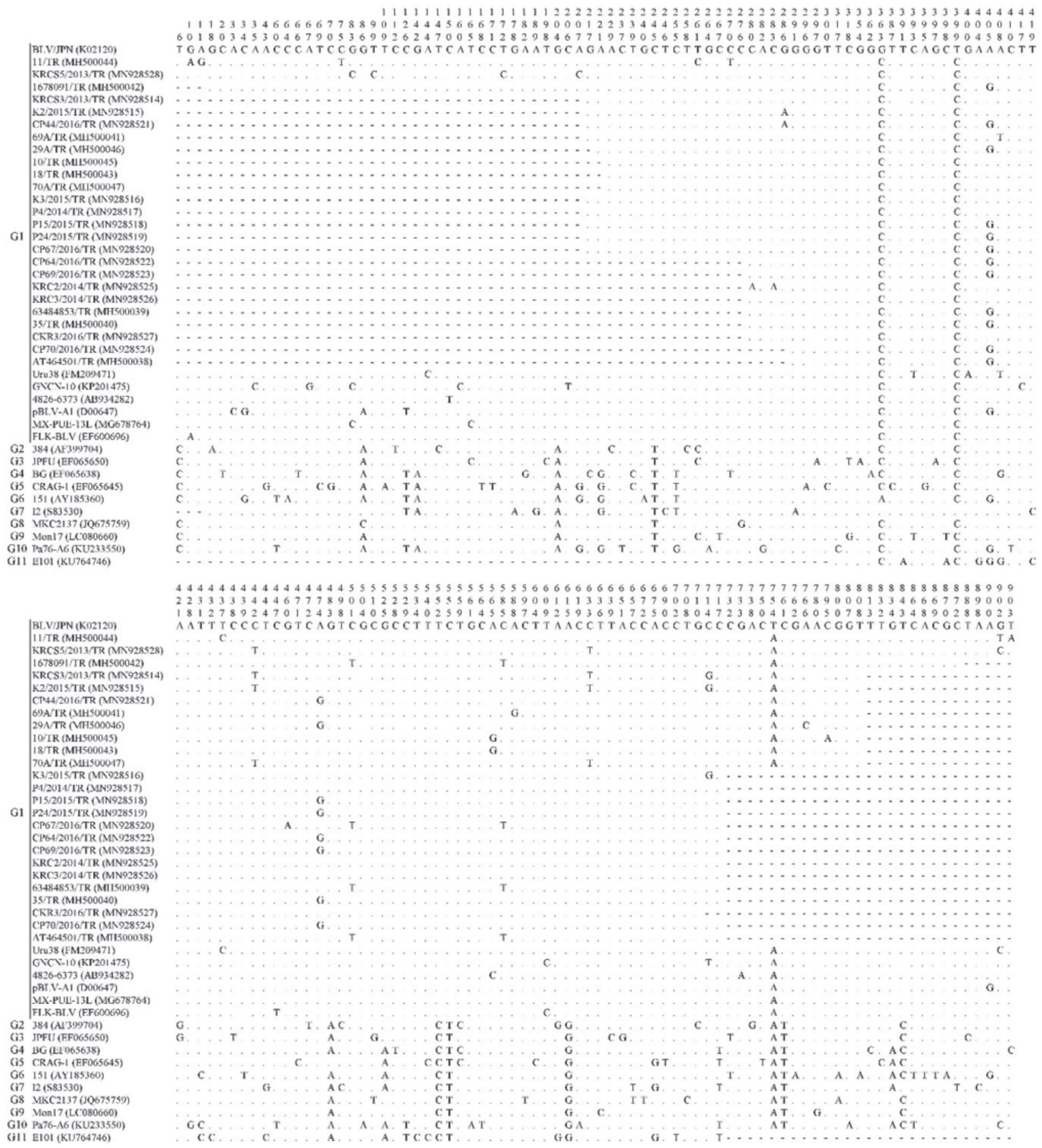

Fig. 3. Alignment of BLV partial and full-length env gp51 nucleotide sequences of 25 Turkish BLV strains and reference sequences, representing all 11 BLV genotypes, from GenBank. All strains are shown by name and

GenBank accession numbers in the parentheses. The strains investigated in this study are indicated by $(*)$. Dots indicate identity with the Japanese strain (K02120), which was used as a reference in this study, and numbers above the sequences denote the nucleotide numbers of the reference. 

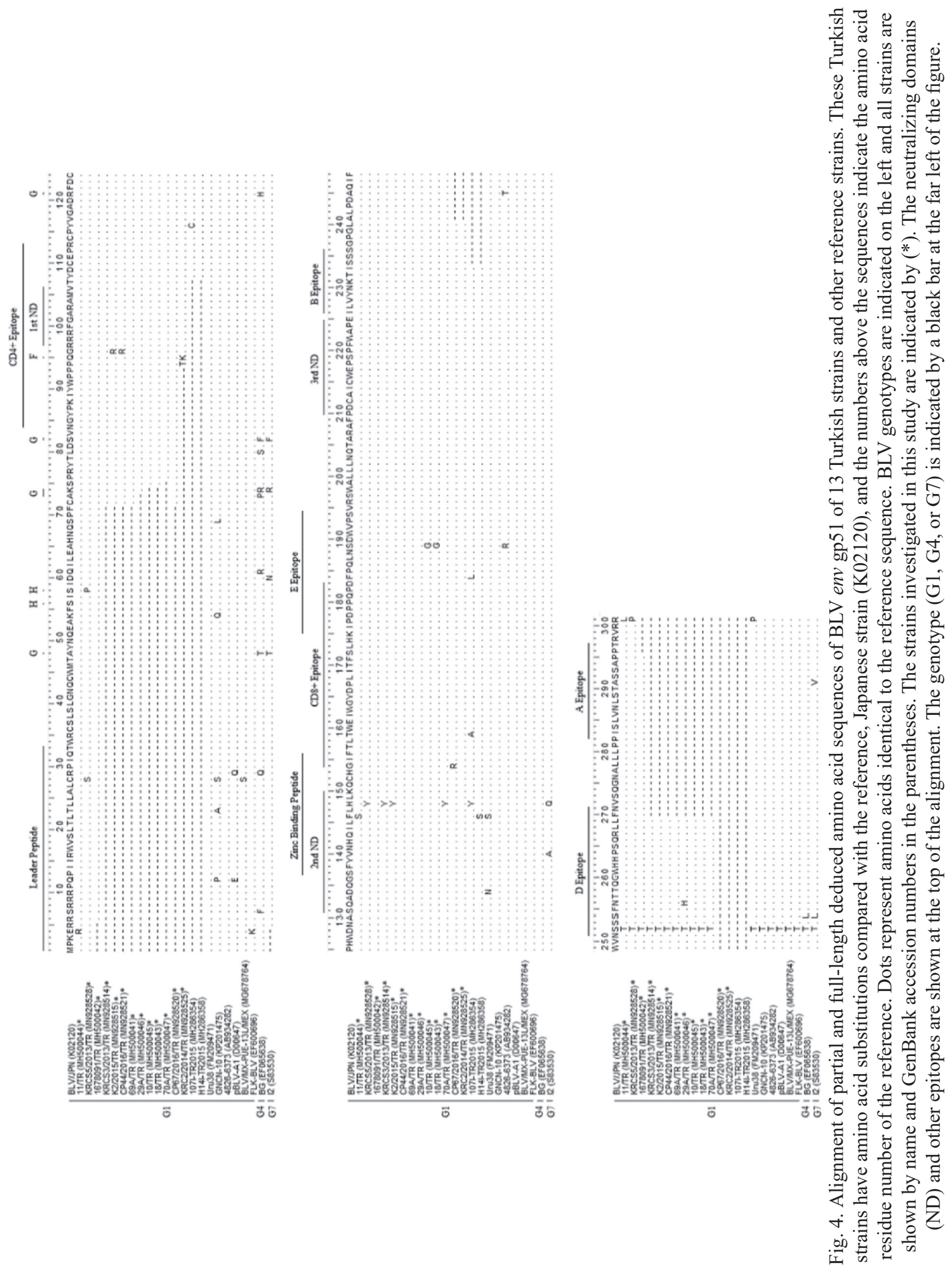
T399C, A405G, A408T, T437C, C442T, G460A, A474G, C501T, A565G, C585T, A588G, C633T, C714G, T754A, A766C, C795A, G902C, G902T and T903A (Fig. 3).

To provide greater insights into the genetic diversity of the Turkish BLV genotype 1 strains, we aligned the deduced amino acid sequences of the 25 env gp51 sequences (partial or full-length). The data demonstrated that fourteen different amino acid substitutions were identified among the thirteen strains, whereas there were no differences among the remaining twelve Turkish BLVs (Fig. 4).

\section{Discussion}

BLV has been circulating in Turkey for a long time, and many studies have been carried out to determine the prevalence of BLV infection since 1991 (BURGU et al.,1991; AKÇA et al., 1996; UYSAL etal., 1998; BURGU et al., 2005). However, information on its genetic characterization is limited. In this study, we aimed to gain an insight into the genotype(s) and genetic variability of the BLV strains in Turkey. The phylogenetic analysis and also amino acid data clearly showed that our BLVs belonged to genotype 1 (Fig. 2 and Fig. 4). To date, there have been only three studies reporting the molecular characterization of BLVs in Turkey that represent genotypes 1 and 4 (ALKAN et al., 2011; DEGIRMENCI, 2011; DOGAN et al., 2020). Studies from different countries/continents have revealed genotype 1 as the most dominant genotype, whereas genotype 4 is the second most common (OCHIRKHUU et al., 2016; POLAT et al., 2017b). Genotype 1 is distributed across almost all continents, and it is particularly highly prevalent in South and North America, which still have a high prevalence of BLV infection (POLAT et al., 2017b). In addition, genotype 1 is also common in Asian countries such as Japan, Korea, The Philippines, Thailand, and Mongolia (MATSUMURA et al., 2011; LEE et al., 2015; POLAT et al., 2015; LEE et al., 2016; OCHIRKHUU et al., 2016). However, in Europe genotype 1 was only detected in Germany (FECHNER et al., 1997). As stated in previous studies, the widespread distribution of BLV, and also its genotypes, within and between distant geographical locations may be based on livestock trading (POLAT et al., 2017b). It is not known when BLV entered Turkey. However, BLV infection was first detected in imported, highly productive, pedigree Holstein and Swedish dairy cows on a farm in Turkey (HAKIOGLU, 1962). Subsequent studies also detected high seropositivity rates on this farm and other farms that had a relationship with this farm in terms of animal production (BURGU et al., 1991; BURGU et al., 2005). The higher frequency of BLV genotype 1 in Turkey might correspond to its initial entrance and, then, its spread all over the country through animal movements. On the other hand, the fact that the importation of live animals from countries with BLV infection, with high rates in herds and individual levels, should be hypothesized for subsequent studies. Live animals had been imported from Europe, the US, and also South America (Brazil, Uruguay, etc.) to Turkey for a long time, as reported in the Global Agricultural Information Network Report (Report Number: TR8027 with date 8/31/2018) (https://apps.fas.usda.gov/, https://www.trademap.org/). Different genotypes (genotypes 1, 2, 4, 5, 6, 7, and 9) were circulating in these countries (FECHNER et al., 1997; CAMARGOS et al., 2007; ZHAO and BUEHRING, 2007; MORATORIO et al., 2010). Considering the history of animal importation into Turkey, the detection of BLV genotype 1, which is the most dominant, was not surprising. Also, we believe that the detection of genotype 4 in the Marmara region (DEGIRMENCI, 2011), which is a very important region for dairy cattle production, could be related to live animal imports. The presence of more than one genotype in a country or even in a herd has previously been reported in many studies (OCHIRKHUU et al., 2016; YU et al., 2019). Briefly, additional genotypes may be circulating in Turkey and therefore further studies are needed to substantiate this opinion.

In addition to the detection of genotype(s) circulating in a herd or country, genetic characterization is very important to understand the evolution of the virus. The alignment of our BLVs with that of the Japanese K02120 strain demonstrated some nt substitutions in the env gp51 region (Fig. 3 ). Among the mutations, sixteen were synonymous mutations (C75T, T99C, A207C, T261C, C270T, 
G363C, T399C, A405G, A408T, A474G, C501T, C585T, A588G, C633T, C714G, and C795A), the remaining sixteen were non-synonymous mutations (G10A, A11G, G83C, T172C, C280A, C283A, G286A, T437C, C442T, G460A, A565G, T754A, A766C, G902C, G902T, and T903A). Furthermore, twelve of the mutations (A11G, C75T, T172C, C280A, C283A, G286A, G460A, C501T, C585T, A588G, A766C and C795A) were identified as unique mutations. These mutations were traced to the fourteen different amino acid substitutions in thirteen BLV strains. Four of them were semiconservative (C28S, P94T, H148Y and R301P) and five were conservative substitutions (S58P, Q95K, S189G, S252T and N256H), while the remaining five (E4R, G96R, F146S, G154R, and R301L) were non-conservative substitutions. On the basis of the alignment of the deduced amino acid sequences (Fig. 4), two different amino acid substitutions were identified in the Env leader peptide; E4R and C28S. Comparisons of conformational $(\mathrm{F}, \mathrm{G}$, and $\mathrm{H})$ and linear (A, B, D, and E) epitopes revealed that A, B and $\mathrm{G}$ were conserved. The $\mathrm{H}$-epitope at residue 58 , the $\mathrm{F}$ epitope at residue 95, the E epitope at residue 189 and the D epitope at residue 256 differed, and the substitutions S58P, Q95K and N256H were unique. The amino acid substitution was within the conformational epitope $\mathrm{H}$, which was previously found to influence epitope $\mathrm{H}$-specific monoclonal antibody recognition (JOHNSTON et al., 2002). $\mathrm{N} 256 \mathrm{H}$ amino acid substitution in the D-epitope was found in only one strain, and its biological importance is unclear. However, amino acid changes in the D epitope were previously expected to affect the fusion and infectivity of BLV (GATOT et al., 2002; LEE et al., 2016). Furthermore, S189G amino acid substitution within the E epitope was observed, similar to that previously reported (ROLA-ŁUSZCZAK et al., 2013; POLAT et al., 2015; OCHIRKHUU et al., 2016; YANG et al., 2019). Of the neutralizing domains, the $1^{\text {st }}$ and $3^{\text {rd }}$ were conserved, while two amino acid substitutions, F146S and H148Y, were located in the $2^{\text {nd }} \mathrm{ND}$, and they were observed in one and three Turkish BLVs, respectively. The substitution F146S has been reported earlier (MORATORIO et al., 2010; ROLA-ŁUSZCZAK et al., 2013), whereas the substitution H148Y is unique. Although the role of these mutations in affecting infectivity is unknown, on the basis of the predicted tertiary structure of gp51, they are located on the surface of the env gp51 and could affect viral fusion and the infectivity of BLV in vivo (GATOT et al., 2002). The substitutions at residue P94T and G96R were located in the CD4+ T-cell epitope, and they were also unique. Another mutation, G154R, which was found in only one BLV, occurred in the CD8+ T-cell epitope. However, this mutation did not seem to affect the detection capability of the serological test because all our samples were positive by both ELISA and PCR assays. Since the CD8+ T-cell epitope also overlaps with the zinc-binding peptide, which is critical for viral fusion and infectivity in vivo, any amino acid changes within this region may alter BLV infectivity (PLUTA et al., 2017). Lastly, one of the strains had proline at residue 301 (P301), similar to the strains reported from Uruguay genotype 1 strains (MORATORIO et al., 2010) and Thailand genotype 6 strains (LEE et al., 2016), whereas another had leucine at residue 301 (L301), which has not been described previously.

In conclusion, in this study, only one BLV genotype (genotype 1) was identified according to the genetic analysis of partial and/or full-length BLV env gp51. On the basis of our study and the other previous studies (ALKAN et al., 2011; DEGIRMENCI, 2011), it is possible to say that at least two BLV genotypes (genotypes 1 and 4) have been circulating over the last decade in Turkey. Molecular characterization of the env gp51 of these BLV strains showed relatively high nucleotide sequence conservation, however, some mutations in specific regions of the env gene were detected. This study, which presents the genotypes of relatively old BLV strains, will help us to better understand the genetic diversity of BLV strains and the molecular epidemiology of the infection in Turkey and the world from the past to the present. Further studies are needed to determine the genotype(s) circulating, to define immunogenicity and pathogenicity between different genotypes, and to investigate the interaction between the BLV genotypes and animal importation between the countries. They will make it possible to provide supplementary information 
for the development of more effective prevention and control measures against this infection in Turkey and also other countries.

\section{Acknowledgment}

This study was supported by a grant from Ankara University Scientific Research Projects Coordination Unit (Project No.19L0239007). The authors confirm that the ethical policies of the journal, as noted on the journal's author guidelines page, have been adhered to, and Ankara University Local Ethics Committee approval has been received (Ethics approval number: 2019-5-51).

\section{References}

AKÇA, Y., F. ALKAN, S. BILGE, T. KARAOĞLU, A. OZKUL, I. BURGU, O. R. KAADEN (1996): The investigation of bovine leukosis virus (BLV) specific antibodies in milk and serum samples from dairy cattle using Enzyme Linked Immunosorbent Assay (ELISA) and Agar Jel Immunodiffusion (AGID) test. Ankara Univ. Vet. Fak. Derg. 43, 53-59.

DOI: $10.1501 /$ Vetfak_0000000726

ALKAN, F., T. C. OGUZOGLU, M. O. TIMURKAN, Z. KARAPINAR (2011): Characterisation of env and gag gene fragments of bovine leukemia viruses (BLVs) from cattle in Turkey. Arch. Virol. 156, 1891-1896.

DOI: $10.1007 / \mathrm{s} 00705-011-1060-6$

BAZZUCCHI, M., C. ISCARO, C. CASCIARI, M. GIAMMARIOLI, F. FELIZIANI (2019): Molecular characterization of Italian bovine leukemia virus isolates reveals the presence of distinct phylogenetic clusters. Arch. Virol. 164, 1697-1703.

DOI: $10.1007 / \mathrm{s} 00705-019-04255-4$

BRUCK, C., S. MATHOT, D. PORTETELLE, C. BERTE, J. D. FRANSSEN, P. HERION, A. BURNY (1982): Monoclonal antibodies define eight independent antigenic regions on the bovine leukemia virus (BLV) envelope glycoprotein gp51. Virology 122, 342-352.

DOI: 10.1016/0042-6822(82)90234-3.

BURGU, I., F. ALKAN, T. KARAOGLU, S. BILGEDAGALP, K. CAN-SAHNA, B. GUNGOR, B. DEMIR (2005): Control and eradication programme of enzootic bovine leucosis (EBL) from selected dairy herds in Turkey. Dtsch. Tierarztl. Wochenschr. 112, 271-274.

BURGU, I., H. K. URMAN, O. R. KAADEN, U. TRUYEN, Y. AKCA, G. ALCIGIR, S. BERKIN, F. ALKAN, A. ATASEVER (1991): Sero-epidemiological and pathological studies on enzootic bovine leukosis in Turkey. Dtsch. Tierarztl. Wochenschr. 98, 226-228.

CAMArgos, M. F., A. PEREDA, D. STANCEK, M. A. ROCHA, J. K. DOSREIS, I. GREISER-WILKE, R. C. LEITE (2007): Molecular characterization of the env gene from Brazilian field isolates of bovine leukemia virus. Virus Genes 34, 343-350.

DOI: $10.1007 / \mathrm{s} 11262-006-0011-x$.
DEGIRMENCI, H. (2011): Detection of bovine leukemia virus by using serological and molecular methods in Marmara region, $\mathrm{PhD}$ Thesis, Istanbul University, Istanbul, Turkey.

DOGAN, F., BILGE DAGALP, S., DIK, B., FARZANI, T. A., ALKAN F (2020): Detection of genotype 1 bovine leukemia virus from a C. schultzei pool: Do Culicoides spp. have a role on the transmission of bovine leukemia virus? Infect Genet Evol. 85, 104469.

DOI: $10.1186 / \mathrm{s} 12985-017-0876-4$

FECHNER, H., P. BLANKENSTEIN, A. C. LOOMAN, J. ELWERT, L. GEUE, C. ALBRECHT, A. KURG, D. BEIER, O. MARQUARDT, D. EBNER (1997): Provirus variants of the bovine leukemia virus and their relation to the serological status of naturally infected cattle. Virology. 237, 261-269.

DOI: $10.1006 /$ viro.1997.8784.

FECHNER, H., A. KURG, L. GEUE, P. BLANKENSTEIN, G. MEWES, D. EBNER, D. BEIER (1996): Evaluation of Polymerase Chain Reaction (PCR) Application in Diagnosis of Bovine Leukaemia Virus (BLV) Infection in Naturally Infected Cattle. Zentralbl. Veterinarmed. B. 43, 621-630.

DOI: 10.1111/j.1439-0450.1996.tb00361.x

GATOT, J. S., I. CALLEBAUT, C. VAN LINT, D. DEMONTE, P. KERKHOFS, D. PORTETELLE, A. BURNY, L. WILLEMS, R. KETTMANN (2002): Bovine leukemia virus SU protein interacts with zinc, and mutations within two interacting regions differently affect viral fusion and infectivity in vivo. J. Virol. 76, 7956-7967.

DOI: 10.1128/JVI.76.16.7956-7967.2002.

GAUTAM, S., N. MISHRA, S. KALAIYARASU, S. K. JHADE, R. SOOD (2018): Molecular Characterization of Bovine Leukaemia Virus (BLV) strains reveals existence of Genotype 6 in Cattle in India with evidence of a new subgenotype. Transbound. Emerg. Dis. 65, 1968-1978.

DOI: $10.1111 /$ tbed.12979

GLOBAL AGRICULTURAL INFORMATION NETWORK TURKEY LIVESTOCK ANNUAL REPORT (2018): Report Number: TR8027 with date 8/31/201 (Accessed on 17 February 2020) https://apps.fas.usda.gov/newgainapi/ api/report/downloadreportbyfilename?filename Livestock\%20and\%20Products\%20Annual_Ankara_ Turkey_9-7-2018.pdf

HAKIOGLU, F (1962): The first report on hematological research in terms of leukocyte in Karacabey stud cattle. Türk Vet. Dern. Derg. 186, 167-175.

JOHNSTON, E. R., L. M. ALBRITTON, K. RADKE (2002): Envelope proteins containing single amino acid substitutions support a structural model of the receptorbinding domain of bovine leukemia virus surface protein. J. Virol. 76, 10861-10872.

DOI: $10.1128 /$ jvi.76.21.10861-10872.2002

JOHNSTON, E. R., K. RADKE (2000): The SU and TM envelope protein subunits of bovine leukemia virus are 
linked by disulfide bonds, both in cells and in virions. J. Virol. 74, 2930-2935.

DOI: 10.1128/JVI.74.6.2930-2935.2000

KUMAR, S., G. STECHER, M. LI, C. KNYAZ, K. TAMURA (2018): MEGA X: Molecular evolutionary genetics analysis across computing platforms. Mol. Biol. Evol. 35, 1547-1549.

DOI: $10.1093 / \mathrm{molbev} / \mathrm{msy} 096$.

LARSSON, A. (2014): AliView: A fast and lightweight alignment viewer and editor for large datasets. Bioinformatics 30, 3276-3278.

DOI: 10.1093/bioinformatics/btu531

LEE, E., E. J. KIM, H. K. JOUNG, B. H. KIM, J. Y. SONG, I. S. CHO, K. K. LEE, Y. K. SHIN (2015): Sequencing and phylogenetic analysis of the gp51 gene from Korean bovine leukemia virus isolates. Virol. J. 12, 64.

DOI: 10.1186/s12985-015-0286-4.

LEE, E., E. J. KIM, J. RATTHANOPHART, R. VITOONPONG, B. H. KIM, I. S. CHO, J. Y. SONG, K. K. LEE, Y. K. SHIN (2016): Molecular epidemiological and serological studies of bovine leukemia virus (BLV) infection in Thailand cattle. Infect. Genet. Evol. 41, 245-254.

DOI: 10.1016/j.meegid.2016.04.010

MAMOUN, R. Z., M. MORISSON, N. REBEYROTTE, B. BUSETTA, D. COUEZ, R. KETTMANN, M. HOSPITAL, B. GUILLEMAIN (1990): Sequence variability of bovine leukemia virus env gene and its relevance to the structure and antigenicity of the glycoproteins. J. Virol. 64, 4180-4188.

MATSUMURA, K., E. INOUE, Y. OSAWA, K. OKAZAKI (2011): Molecular epidemiology of bovine leukemia virus associated with enzootic bovine leukosis in Japan. Virus Res. 155, 343-348.

DOI: 10.1016/j.virusres.2010.11.005.

MORATORIO, G., G. OBAL, A. DUBRA, A. CORREA, S. BIANCHI, A. BUSCHIAZZO, J. CRISTINA, O. PRITSCH (2010): Phylogenetic analysis of bovine leukemia viruses isolated in South America reveals diversification in seven distinct genotypes. Arch. Virol. 155, 481-489.

DOI: 10.1007/s00705-010-0606-3.

OCHIRKHUU, N., S. KONNAI, R. ODBILEG, A. NISHIMORI, T. OKAGAWA, S. MURATA, K. OHASHI (2016): Detection of bovine leukemia virus and identification of its genotype in Mongolian cattle. Arch. Virol. 161, 985-991.

DOI: $10.1007 / \mathrm{s} 00705-015-2676-8$.

OIE (World Organization for Animal Health) (2018): Enzootic bovine leucosis. OIE Terresterial Man. 2018. URL https:// www.oie.int/fileadmin/Home/eng/Health_standards/ tahm/2.04.10_EBL.pdf

PANDEY, G. S., E. SIMULUNDU, D. MWIINGA, K. L. SAMUI, A. S. MWEENE, M. KAJIHARA, A. MANGANI, R. MWENDA, J. NDEBE, S. KONNAI, A. TAKADA
(2017): Clinical and subclinical bovine leukemia virus infection in a dairy cattle herd in Zambia. Arch. Virol. 162, 1051-1056.

DOI: $10.1007 / \mathrm{s} 00705-016-3205-0$.

PHIRI, M. M., E. KAIMOYO, K. CHANGULA, I. SILWAMBA, H. M. CHAMBARO, P. KAPILA, M. KAJIHARA, M. SIMUUNZA, J. B. MUMA, G. S. PANDEY, A. TAKADA, A. S. MWEENE, S. CHITANGA, E. SIMULUNDU (2019): Molecular detection and characterization of genotype 1 bovine leukemia virus from beef cattle in the traditional sector in Zambia. Arch. Virol. $164,2531-2536$.

DOI: $10.1007 / \mathrm{s} 00705-019-04350-6$.

PLUTA, A., M. ROLA-ŁUSZCZAK, P. KUBIŚ, S. BALOV, R. MOSKALIK, B. CHOUDHURY, J. KUŹMAK (2017): Molecular characterization of bovine leukemia virus from Moldovan dairy cattle. Arch. Virol. 162, 1563-1576.

DOI: $10.1007 / \mathrm{s} 00705-017-3241-4$

POLAT, M., A. OHNO, S. TAKESHIMA, J. KIM, M. KIKUYA, Y. MATSUMOTO, C. N. MINGALA, M. ONUMA, Y. AIDA (2015): Detection and molecular characterization of bovine leukemia virus in Philippine cattle. Arch. Virol. 160, 285-296.

DOI: $10.1007 / \mathrm{s} 00705-014-2280-3$

POLAT, M., S. TAKESHIMA, K. HOSOMICHI, J. KIM, T. MIYASAKA, K. YAMADA, M. ARAINGA, T. MURAKAMI, Y. MATSUMOTO, V. DE LA BARRA DIAZ, C. J. PANEI, E. T. GONZÁLEZ, M. KANEMAKI, M. ONUMA, G. GIOVAMBATTISTA, Y. AIDA (2016): A new genotype of bovine leukemia virus in South America identified by NGS-based whole genome sequencing and molecular evolutionary genetic analysis. Retrovirology 13,4 .

DOI: $10.1186 / \mathrm{s} 12977-016-0239-\mathrm{Z}$

POLAT, M., H. H. MOE, T. SHIMOGIRI, K. K. MOE, S. TAKESHIMA, Y. AIDA (2017a): The molecular epidemiological study of bovine leukemia virus infection in Myanmar cattle. Arch. Virol. 162, 425-437.

DOI: $10.1007 / \mathrm{s} 00705-016-3118-\mathrm{y}$

POLAT, M., S. TAKESHIMA, Y. AIDA(2017b): Epidemiology and genetic diversity of bovine leukemia virus. Virol. J. $14,209$.

DOI: $10.1186 / \mathrm{s} 12985-017-0876-4$

ROLA-ŁUSZCZAK, M., A. PLUTA, M. OLECH, I. DONNIK, M. PETROPAVLOVSKIY, A. GERILOVYCH, I. VINOGRADOVA, B. CHOUDHURY, J. KUŹMAK (2013): The molecular characterization of bovine leukaemia virus isolates from Eastern Europe and Siberia and its impact on phylogeny. PLoS One 8, 1-8.

DOI: 10.1371/journal.pone.0058705

UYSAL, A., H. YILMAZ, T. BILAL, E. BERRIATUA, U. BAKIREL, M. ARSLAN, M. ZERIN, H. TAN (1998): Seroprevalence of enzootic bovine leukosis in Trakya 
district (Marmara region) in Turkey. Prev. Vet. Med. 37, 121-128.

DOI: $10.1016 / \mathrm{S} 0167-5877(98) 00108-1$

YANG, Y., L. CHEN, M. DONG, W. HUANG, X. HAO, Y. PENG, Z. GONG, A. QIN, S. SHANG, Z. YANG (2019): Molecular characterization of bovine leukemia virus reveals existence of genotype 4 in Chinese dairy cattle. Virol. J. 16, 1-7.

DOI: $10.1186 / \mathrm{s} 12985-019-1207-8$.

YANG, Y., P. J. KELLY, J. BAI, R. ZHANG, C. WANG (2016): First molecular characterization of bovine leukemia virus infections in the caribbean. PLoS One. 11, 1-12.

DOI: 10.1371/journal.pone.0168379
YU, C., WANG, X., ZHOU, Y., WANG, Y., ZHANG, X., ZHENG, Y (2019): Genotyping bovine leukemia virus in dairy cattle of Heilongjiang, northeastern China. BMC Vet Res. $15,179$.

DOI: $10.1186 / \mathrm{s} 12917-019-1863-3$

ZHAO, X., G. C. BUEHRING (2007): Natural genetic variations in bovine leukemia virus envelope gene: Possible effects of selection and escape. Virology 366, 150-165.

DOI: $10.1016 /$ j.virol.2007.03.058

\section{ALKAN, F., I. KARAYEL-HACIOGLU, S. DURAN YELKEN, N. COSKUN: Određivanje genotipa i molekularna karakterizacija virusa goveđe leukemije u Turskoj. Vet. arhiv 91, 237-247, 2021. \\ SAŽETAK}

Virus goveđe leukemije (BLV) raširen je po cijelom svijetu i uzrokuje znatne ekonomske gubitke u proizvodnji. $\mathrm{U}$ istraživanju, s ciljem identifikacije genotipova i molekularne karakterizacije sojeva BLV-a, analizirano je 25 sojeva BLV-a goveda iz 6 stada, uzgajanih u nekoliko turskih zemljopisnih regija. Filogenetska analiza osnovana na djelomičnoj ili punoj sekvenciji gena env gp51 BLV-a pokazala je da svi turski virusi goveđe leukemije pripadaju genotipu 1. Poravnanje izvedenih aminokiselinskih sekvencija pokazalo je 14 supstitucija aminokiselina u različitim regijama gena env gp51. Ovo istraživanje dopunjuje znanje o BLV-u u Turskoj. Potrebna su daljnja istraživanja kako bi se razumjela molekularna epidemiologija i proveo sveobuhvatan program kontrole BLV u Turskoj.

Ključne riječi: virus goveđe leukemije; genotip 1; glikoprotein ovojnice (gp51); molekularna karakterizacija; Turska 
